\title{
Article/Artigo
}

\section{Comparison of Bothropoides jararaca bites with and without envenoming treated at the Vital Brazil Hospital of the Butantan Institute, State of São Paulo, Brazil}

\author{
Comparação dos acidentes causados por Bothropoides jararaca com e sem envenenamento \\ atendidos no Hospital Vital Brazil do Instituto Butantan, Estado de São Paulo
}

\author{
Alessandra Furtado Nicoleti ${ }^{1}$, Carlos Roberto de Medeiros $^{2}$, Marcelo Ribeiro Duarte ${ }^{3}$ and Francisco Oscar \\ de Siqueira França ${ }^{2,4}$
}

\begin{abstract}
Introduction: This study analyses the cases of all bites (including dry bites) caused by Bothropoides jararaca attended at the Vital Brazil Hospital of the Butantan Institute, State of São Paulo, Brazil. Methods: A retrospective study was conducted of patients bitten by Bothropoides jararaca $(n=792)$ from January 1990 to December 2004. The characteristics of the snake specimen, data related to the accident and clinical manifestations on admission were obtained from patient medical records. Results: The majority of the cases in this study were caused by female and juvenile snakes. No stomach contents were found in $93.4 \%$ of the snake specimens after dissection. No statistical difference was observed between the occurrence of dry bites and the maturity or sex of the snake. The median SVL of snakes in mild and moderate cases was $40.5 \mathrm{~cm}$ and in severe cases, SVL increased to $99 \mathrm{~cm}$. Necrosis was more common in the digits of the feet and hands $(4.8 \%)$ compared to the other body regions (1.8\%). A significant difference was verified between severity and a time interval greater than six hours from the bite to hospital admission. A significant association was verified between gingival bleeding and abnormal blood coagulability. In accidents caused by adult snakes, necrosis was more frequent (7.2\%) compared to accidents caused by juvenile snakes (1\%). Conclusions: In this work, the association between certain epidemiological data and the evolution of biological parameters in the clinical course of Bothrops sensu latu accidents were highlighted, contributing to the improvement of snake bite assistance.
\end{abstract}

Key-words: Bothrops. Bothropoides. Snake bites. Envenoming. Brazil. Clinical aspects.

\section{RESUMO}

Introdução: Neste estudo, analisou-se todos os casos de picadas (incluindo picadas secas) causadas por Bothropoides jararaca atendidos no Hospital Vital Brazil do Instituto Butantan, São Paulo, Brasil. Métodos: Estudo retrospectivo em que foram incluídos pacientes atendidos no Hospital Vital Brazil do Instituto Butantan, picados por serpentes da espécie Bothropoides jararaca ( $\mathrm{n}-792)$ entre 1990 a 2004 . Os dados foram obtidos através de prontuários médicos. Resultados: No presente estudo, a maioria dos acidentes foi causada por serpentes fêmeas e filhotes. Não havia presença de conteúdo estomacal em 93,4\% das serpentes dissecadas. Não houve diferença estatística entre a ocorrência de picada seca e o sexo da serpente. O comprimento rostro cloacal das serpentes nos casos leves e moderados foram $40,5 \mathrm{~cm}$ e nos casos severos $99 \mathrm{~cm}$. Necrose foi mais comum nos dedos dos pés e das mãos $(4,8 \%)$ em comparação com outras regiões do corpo $(1,8 \%)$. Houve diferença estatística entre a gravidade e o intervalo de tempo entre a picada e a admissão hospitalar superior a seis horas. Encontramos uma associação significativa entre gengivorragia e incoagulabilidade sanguínea. Nos acidentes causados por serpentes adultas, a necrose foi mais frequente $(7,2 \%)$ quando comparado aos acidentes causados por serpentes filhotes (1\%). Conclusões: Neste estudo, destaca-se a associação entre os dados epidemiológicos e biológicos em relação à evolução do quadro clínico nos acidentes botrópicos, contribuindo para a melhoria da assistência nos acidentes ofídicos.

Palavras-chaves: Bothrops. Bothropoides. Acidentes ofídicos. Envenenamento. Brasil. Aspectos clínicos.

1. Pos-graduation Program, Department of Infectious and Parasitic Diseases, Faculty of Medicine, University of São Paulo, São Paulo, SP, Brazil. 2. Vital Brazil Hospital, Instituto Butantan, São Paulo, SP., Brazil. 3. Herpetology Laboratory, Instituto Butantan, São Paulo, SP, Brazil. 4. Division of Infectious and Parasitic Diseases, Clinical Hospital of Faculty of Medicine, University of São Paulo, São Paulo, SP, Brazil.

Address to: Dr. Francisco Oscar de Siqueira França. Hospital Vital Brazil. Av. Vital Brazil 1500, 05503-900 São Paulo, SP, Brazil.

Phone/fax: $55113726-7962$

e-mail: fosfranca@gmail.com

Received in 29/06/2010

Accepted in 06/08/2010

\section{INTRODUCTION}

In Brazil, nine genera of venomous snakes are recognized: Bothrops, Bothropoides, Bothriopsis, Bothrocophias, Rhinocerophis, Crotalus, Lachesis, Leptomicrurus and Micrurus ${ }^{1}$. Due to similar manifestations and treatment with the same antivenom, the first five genera are grouped here as Bothrops sensu lato. These snakes are responsible for 86.9\% (Bothrops sensu lato), 8.7\% (Crotalus), 3.6\% (Lachesis) and 0.8\% (Leptomicrurus and Micrurus) of accidents involving venomous snakes ${ }^{2}$.

In 2009, 21,446 cases of snakebite were reported, with a fatality rate of $0.4 \%$. The highest incidences were recorded in the southeast (28\%), north (27\%) and northeast $(24 \%)$ of Brazil ${ }^{4}$. There is a predominance of cases in the hot and rainy months (October to April), affecting mostly rural, male workers, aged between 10 and 40 years of age ${ }^{5}$. In the northeast, most accidents occur between April and May, while in the north, cases occur in the first months of the year ${ }^{4}$.

The Bothropoides jararaca, formerly Bothrops jararaca ${ }^{5}$, species has high adaptive capacity, thriving in urban and wild environments ${ }^{6}$, and it is the most common species in the southeast ${ }^{7}$.

The venom has local acute inflammatory, coagulative and hemorrhagic effects ${ }^{8}$. The most common signs and symptoms include pain, swelling and bleeding, occurring within the first six hours following envenomation. Six hours after the accident, blistering, bruising, necrosis, secondary infection sites and, in severe cases, acute renal failure occur. Frequently the blood clotting time (CT) is increased ${ }^{9}$.

Bothrops sensu lato envenomation severity is classified as mild, moderate and severe. A dry bite is defined here as a bite without clinical signs or systemic envenoming ${ }^{10}$. The number of dry bites which do not cause envenoming is not known. When considering all Bothrops sensu lato bites, most studies in Brazil do not include dry bites. According to the World Health Organization (WHO), $25 \%$ to $35 \%$ of all cases of 
snakebites worldwide are dry bites ${ }^{11}$. Silveira and Nishioka ${ }^{12}$ state that in dry bites, the amount of venom delivered to the victim is negligible.

This study analyzed the cases of all bites (including dry bites) caused by Bothropoides jararaca attended at the Vital Brazil Hospital (HVB) of the Butantan Institute, São Paulo, Brazil, only when the snake was brought by the victim. The study analyzed the epidemiological, clinical and laboratorial data in these cases.

\section{METHODS}

Retrospective study of data obtained from medical records for all patients attended at the HVB with snake bite caused by the snake species Bothropoides jararaca. The snake specimens brought by the patients were identified and stomach contents were analyzed by the Herpetology laboratory of the Butantan Institute. Data collection and analysis covered a period of 15 years, between 1990 and 2004.

The information collected included epidemiological data from the patient (age, sex and geographic area), characteristics of the snake specimen (sex, maturity, length and stomach contents), data related to the accident (date and time of the accident, the anatomical site, presence of incisions, tourniquets, substances applied to the site), clinical manifestations on admission: presence of signs and symptoms including pain, local hemorrhaging, edema, erythema, ecchymosis, gingival bleeding, blistering, infection, local wound discharge, necrosis, systemic hemorrhaging, sepsis and acute renal failure. Blood CT was measured on admission and the quantity in vials of serotherapy was documented.

The severity classification was established according to Brazilian Ministry of Health guidelines ${ }^{13}$. These guidelines define dry bite as a case in which patients show no signs or symptoms consistent with envenoming and present normal blood CT. Mild cases are defined as the presence of mild local signs, such as edema. Moderate cases include regional edema, and severe cases are defined as the presence of swelling around the full length of the affected limb and/or acute renal failure and/or shock, and/or severe hemorrhaging. These definitions do not take into account normal or abnormal blood CT.

All the patients were divided into three groups according to age: children (12 years), adults (13-59 years) and elderly individuals (above 60 years).

The maturity of the snake specimens were classified according to snout-vent length (SVL): adults above $65 \mathrm{~cm}$ in males and above $75 \mathrm{~cm}$ in females ${ }^{6}$. The stomach contents were classified according to the presence or absence of food.

The data were analyzed with SPSS (Statistical Package for Social Sciences) version 15.0. The Chi-square $\chi^{2}$, Fisher Exact and KolmogorovSmirnov tests were used to establish associations between the variables.

\section{Ethical}

The work was approved by the Ethics in Research Committee of the Faculty of Medicine of the University of São Paulo (CAPPesq no. $0387 / 08$ ).

\section{RESULTS}

A total of 792 patient medical records were included in the study, $628(79.3 \%)$ were male, age ranged from 4 to 80 years-old, with a mean age of $33.23 \pm 17.67$ years-old and median of 31 years-old.

Among the snake specimens, 525 (66.3\%) were female and $481(60.7 \%)$ were juvenile. SVL ranged between $7.5 \mathrm{~cm}$ to $126.5 \mathrm{~cm}$, with a mean length of $52.2 \pm 26.14 \mathrm{~cm}$ and a median length of $42 \mathrm{~cm}$. Stomach contents were present in 49 (6.2\%) snake specimens.
Most accidents occurred between the months of October and April ( $\mathrm{n}=638 ; 80.6 \%)$, with $711(90.2 \%)$ between $7 \mathrm{am}$ and $8 \mathrm{pm}$. The cities directly surrounding central São Paulo carried the highest burden of cases $(\mathrm{n}=646 ; 81.9 \%)$. Analysis verified that $56.8 \%(\mathrm{n}=450)$ of the patients included were working when bitten.

Furthermore, in pre-hospital observations, 221 (27.9\%) patients had used a tourniquet, $17(2.1 \%)$ had made an incision at the site of the bite and 75 (9.5\%) used other substances, for example garlic, tobacco or kerosene, on the site of the bite.

The anatomical areas most affected were: the feet $(n=263 ; 33 \%)$, fingers $(n=205 ; 26 \%), \operatorname{leg}(n=125 ; 16 \%)$, toes $(n=86 ; 11 \%)$ and hands $(\mathrm{n}=79 ; 10 \%)$.

Five hundred and thirty-four $(68.5 \%)$ patients were admitted to HVB less than three hours after the bite and according to severity, $117(14.8 \%)$ patients showed no symptoms of envenoming. Five hundred and thirteen $(68.4 \%)$ cases were classified as mild, $142(17.9 \%)$ as moderate and $20(2.5 \%)$ as severe.

The signs and symptoms of envenoming observed included: pain $(\mathrm{n}=651 ; 82.2 \%)$, edema $(\mathrm{n}=646 ; 81.6 \%)$, ecchymosis $(\mathrm{n}=388 ; 49 \%)$, necrosis $(\mathrm{n}=23 ; 2.9 \%)$, infection $(\mathrm{n}=51 ; 6.4 \%)$ and bleeding at the wound site $(n=273 ; 34.5 \%)$. Blood CT was abnormal in $457(59 \%)$ patients, with $40.8 \%(n=316)$ of cases documented as incoagulable. A median of 3.8 vials of Bothrops antivenom (BAV) were used in all the cases.

Comparison of the epidemiological variables in the absence and presence of envenoming revealed no statistical difference in relation to the sex of the patient $(\mathrm{p}=0.296)$, patient age when divided into child, adult and elderly groups $(p=0.615)$, the sex of the snake $(p=0.386)$, its maturity $(\mathrm{p}=0.381)$ and the presence of stomach contents $(\mathrm{p}=0.236)$. The median SVL of snakes in mild and moderate cases was $40.5 \mathrm{~cm}$, while in the severe cases, the SVL increased to $99 \mathrm{~cm}$. The majority $(71.7 \%)$ of cases occurred during the spring and summer $(\mathrm{p}<0.001)$ (Table 1).

Only 19 (2.4\%) of the patients who used tourniquet had dry bites. Signs of envenoming were less frequent in patients bitten on the arms compared to patients bitten on the legs $(p<0.05)$. The use of a tourniquet was significantly more frequent in patients bitten on the legs $(\mathrm{n}=146 ; 18.7 \%)$ compared to patients bitten on the arms $(n=75 ; 9.6 \%)$. Cases involving the distal limbs (feet, hands and digits) were caused more frequently by juvenile snakes $(n=413 ; 60.1)$ (Table 2).

A significant difference was verified in envenomation severity of patients attended at hospital less than or greater than 6 hours after the accident $(\mathrm{p}<0.05)$ (Table 3). A significant association between the presence of gingival bleeding and blood incoagulability was detected $(\mathrm{p}<0.001)$ (Table 4).

A statistical association was observed in relation to the anatomical site affected and the presence of necrosis, in that necrosis more commonly affected the digits of the hands or feet $(4.8 \%)$ compared to the other body regions (1.8\%). Observation verified that in cases caused by adult snakes, necrosis occurred more frequently (7.2\%) compared to cases caused by juvenile snakes (1\%) (Table 5).

Comparing the three five-year periods studied (1990 to 1994; 1995 to 1999 ; 2000 to 2004), no statistical difference was determined in relation to the use of pre-hospital procedures (tourniquet, incision and substances applied to the site of the bite). However, a difference was observed in the timing between bite and hospital admission for the different periods. Between 1990 and 1994, 36 (53.7\%) patients were admitted after 6 hours, whereas between 1995 and 1999, 19 (28.4\%) patients delayed admission and between 2000 and 2004, only $12(17.9 \%)$ patients delayed admission $(\mathrm{p}<0.05)$. 
TABLE 1 - Distribution of the epidemiological variables of patients bitten by Bothropoides jararaca treated at Vital Brazil Hospital, between 1990 and 2004, with or without dry bite.

\begin{tabular}{|c|c|c|c|c|c|c|}
\hline & \multicolumn{6}{|c|}{ Dry bite } \\
\hline & \multicolumn{2}{|c|}{ no } & \multicolumn{2}{|c|}{ yes } & \multicolumn{2}{|c|}{ total } \\
\hline & $\mathrm{n}$ & $\%$ & $\mathrm{n}$ & $\%$ & $\mathrm{n}$ & $\%$ \\
\hline \multicolumn{7}{|l|}{ Sex of the patient } \\
\hline male & 531 & 67 & 97 & $12.2 \%$ & 628 & $79.3 \%$ \\
\hline female & 144 & 18.2 & 20 & $2.5 \%$ & 164 & $20.7 \%$ \\
\hline \multicolumn{7}{|l|}{ Age of the patient } \\
\hline child & 89 & 11.2 & 12 & 1.5 & 101 & 12.8 \\
\hline adult & 526 & 66.4 & 97 & 12.2 & 623 & 78.7 \\
\hline elderly & 60 & 7.6 & 8 & 1 & 68 & 8.6 \\
\hline \multicolumn{7}{|l|}{ Sex of the snake } \\
\hline male & 172 & 23.9 & 23 & 3.2 & 195 & 27.1 \\
\hline female & 450 & 62.5 & 75 & 10.4 & 525 & 73 \\
\hline \multicolumn{7}{|l|}{ Snake maturity } \\
\hline adult & 176 & 25.5 & 32 & 4.6 & 208 & 30.2 \\
\hline juvenile & 419 & 60.8 & 62 & 9 & 481 & 69.8 \\
\hline \multicolumn{7}{|l|}{ Stomach contents } \\
\hline absence & 598 & 80.2 & 99 & 13.3 & 697 & 93.4 \\
\hline presence & 45 & 6 & 4 & 0.5 & 49 & 6.6 \\
\hline \multicolumn{7}{|l|}{ Seasons of the year } \\
\hline autumn/winter & 190 & 24 & 34 & 4.3 & 224 & 28.3 \\
\hline spring/summer & 485 & 61.2 & 83 & 10.5 & 568 & 71.7 \\
\hline \multicolumn{7}{|l|}{ Use of Tourniquet } \\
\hline no & 473 & 59.7 & 98 & 12.4 & 571 & 72.1 \\
\hline yes & 202 & 25.5 & 19 & 2.4 & 221 & 27.9 \\
\hline \multicolumn{7}{|l|}{ Anatomical Site } \\
\hline arms & 253 & 32 & 55 & 7 & 308 & 39 \\
\hline legs & 418 & 52.9 & 56 & 7.1 & 474 & 60 \\
\hline head and trunk & 3 & 0.4 & 5 & 0.6 & 8 & 1 \\
\hline
\end{tabular}

TABLE 2 - Distribution of snake maturity and the use of a tourniquet, according to anatomical site of the bite.

\begin{tabular}{|c|c|c|c|c|c|c|}
\hline & \multicolumn{6}{|c|}{ Anatomical Site } \\
\hline & \multicolumn{2}{|c|}{ distal limbs } & \multicolumn{2}{|c|}{ proximal limbs } & \multicolumn{2}{|c|}{ total } \\
\hline & $\mathrm{n}$ & $\%$ & $\mathrm{n}$ & $\%$ & $\mathrm{n}$ & $\%$ \\
\hline \multicolumn{7}{|l|}{ Snake maturity } \\
\hline adult & 143 & 20.8 & 65 & 9.5 & 208 & 30.3 \\
\hline \multirow[t]{2}{*}{ juvenile } & 413 & 60.1 & 66 & 9.6 & 479 & 69.7 \\
\hline & \multicolumn{2}{|c|}{ arms } & \multicolumn{2}{|c|}{ legs } & \multicolumn{2}{|c|}{ total } \\
\hline Use of tourniquet & $\mathrm{n}$ & $\%$ & $\mathrm{n}$ & $\%$ & $\mathrm{n}$ & $\%$ \\
\hline no & 233 & 29.8 & 328 & 41.9 & 561 & 71.7 \\
\hline yes & 75 & 9.6 & 146 & 18.7 & 221 & 28.3 \\
\hline
\end{tabular}

TABLE 3 - Time between the bite and hospital admission of patients bitten by Bothropoides jararaca treated at Hospital Vital Brazil, between 1990 and 2004, according to the severity of the envenoming.

\begin{tabular}{|c|c|c|c|c|c|c|}
\hline \multirow{3}{*}{$\begin{array}{l}\text { Time between the bite } \\
\text { and hospital admission }\end{array}$} & \multicolumn{6}{|c|}{ Severity } \\
\hline & \multicolumn{2}{|c|}{ mild/moderate } & \multicolumn{2}{|c|}{ severe } & \multicolumn{2}{|c|}{ total } \\
\hline & $\mathrm{n}$ & $\%$ & $\mathrm{n}$ & $\%$ & $\mathrm{n}$ & $\%$ \\
\hline$<6$ hours & 601 & 97.6 & 15 & 2.4 & 616 & 100 \\
\hline$>6$ hours & 54 & 91.5 & 5 & 8.5 & 59 & 100 \\
\hline
\end{tabular}

TABLE 4 - Blood clotting time and gingival bleeding in patients bitten by Bothropoides jararaca treated at HVB, between 1990 and 2004.

\begin{tabular}{|c|c|c|c|c|c|c|}
\hline \multirow[b]{3}{*}{ Blood Clotting Time } & \multicolumn{6}{|c|}{ Gingival bleeding } \\
\hline & \multicolumn{2}{|c|}{ no } & \multicolumn{2}{|c|}{ yes } & \multicolumn{2}{|c|}{ total } \\
\hline & $\mathrm{n}$ & $\%$ & $\mathrm{n}$ & $\%$ & $\mathrm{n}$ & $\%$ \\
\hline Normal (up to $10 \mathrm{~min}$ ) & 315 & 99.4 & 2 & 0.6 & 317 & 100 \\
\hline Prolonged (11-20 min) & 137 & 97.2 & 4 & 2.8 & 141 & 100 \\
\hline Incoagulable (over $21 \mathrm{~min}$ ) & 284 & 89.9 & 32 & 10.1 & 316 & 100 \\
\hline
\end{tabular}

TABLE 5 - Anatomical site of the envenoming, maturity of the snake and necrosis in patients bitten by Bothropoides jararaca treated at HVB, between 1990 and 2004.

\begin{tabular}{|c|c|c|c|c|c|c|}
\hline \multirow[b]{3}{*}{ Anatomical site } & \multicolumn{6}{|c|}{ Necrosis } \\
\hline & \multicolumn{2}{|c|}{ no } & \multicolumn{2}{|c|}{ yes } & \multicolumn{2}{|c|}{ total } \\
\hline & $\mathrm{n}$ & $\%$ & $\mathrm{n}$ & $\%$ & $\mathrm{n}$ & $\%$ \\
\hline Other anatomical sites & 490 & 98.2 & 9 & 1.8 & 499 & 100 \\
\hline Digits hand/foot & 277 & 95.2 & 14 & 4.8 & 291 & 100 \\
\hline \multicolumn{7}{|l|}{ Maturity of the snake } \\
\hline Adult & 193 & 92.8 & 15 & 7.2 & 208 & 100 \\
\hline Juvenile & 476 & 99 & 5 & 1 & 481 & 100 \\
\hline
\end{tabular}

\section{DISCUSSION}

Analysis of the data collected showed that most envenoming occurred in male patients with an average age of 33 years-old, while at work. This is in agreement with data from other studies published in $\mathrm{Brazi}^{14-19}$. The data also showed that snakes are more active in the hot rainy periods, whereas in the cold dry periods, snakes show little movement. This may be related to low humidity and the lower availability of prey ${ }^{20}$.

Regarding the time of the accident, although venomous snakes in Brazil follow nocturnal habits and rural workers are engaged in field activities during the day, it is during this period that thermoregulation of the snake occurs, when they search for sites with suitable temperatures, not exposed to direct solar radiation. This may increase human-snake encounters ${ }^{20}$. On the other hand, asynchrony between snake activity period and time of the accidents does not imply that inactive hidden snakes cannot bite defensively. In fact, it is noted in the Ministry of Health Manual that $52.3 \%$ of bites occur during normal daylight hours ${ }^{13}$.

The majority of the cases in this study were caused by adult female and juvenile snakes. This could be explained by the fact that female Bothropoides jararaca grow to longer lengths than males ${ }^{20}$. Gravidity is another factor, since females have higher food demands and forage more actively, demanding greater thermal control, consequently, they are more susceptible to human encounters. It is likely that juvenile snakes also cause more bites because visualization of smaller snakes is more difficult. In this case, a juvenile snake can hide coiled under a small leaf, making their presence hard to detect by humans.

The mean SVL was $52.2 \mathrm{~cm}$, which implies a large proportion of juvenile snakes. No stomach contents were found in $93.4 \%$ of the snake specimens, though in regard to this fact, there is little literature available for comparison. The relationship between the presence of food and the severity of bite in Daboia russelii siamensis did not found correlation ${ }^{21}$.

Most ( $81.9 \%)$ cases occurred in metropolitan areas and following decentralization of the distribution of antivenom, the HVB began to serve residents of towns closest to the city of São Paulo. 
Regarding the use of tourniquets, incision and substance use on the bite site, such measures are harmful because they increase the risk of infection and tissue necrosis.

Regarding the anatomical regions affected, the use of boots could prevent $44 \%$ of bites to the feet and toes. The use of appropriately thick gloves would prevent accidents in $36 \%$ of bites affecting the hands and fingers. One study determined that the use of boots and leggings prevent bites to the legs $(16 \%)^{13}$.

The majority of cases caused by Bothropoides jararaca treated at the HVB were admitted less than three hours after the bite. These results are similar to other studies published in Brazil ${ }^{22-24}$.

Concerning severity, approximately $80 \%$ of the cases showed no evidence of envenoming or were classified as mild. This fact explains the low mean number of vials used per case ( 3.8 vials). The most common signs and symptoms in these cases were: pain (82.2\%) and edema (81.6\%). According to Silveira and Nishioka ${ }^{12}$,in Bothrops sp cases, edema is an early sign of envenoming. Many studies report that pain and edema are, respectively, the dominant symptom and sign in Bothrops sensu lato cases, present in more than $90 \%$ of patients s,25,26. $^{20}$.

A study conducted at the HVB between 1981 and 1990 involving 3,139 patients diagnosed with Bothrops sensu lato bites, 517 (16.5\%) patients presented necrosis and $346(11.8 \%)$ presented infection ${ }^{22}$. According with the present data, a significant decrease in these two parameters occurred between 1990 and 2004: 23 (2.9\%) and 51 (6.4\%) of patients, respectively.

In relation to blood CT, $41 \%$ of patients had normal CT, $18.2 \%$ had prolonged CT and incoagulable blood was verified in $40.8 \%$. A study was conducted for the HVB by Ribeiro and Jorge ${ }^{22}$ on 3,139 patients diagnosed as Bothrops sensu lato cases, admitted between 1981 and 1990. In comparison, the authors found 2,990 of CT results, which verified that $42.1 \%$ were normal, $11.2 \%$ were prolonged and $46.7 \%$ were incoagulable.

The length of admission for patients at the HVB, admitted between 1990 and 2004, was 2 days (median). This is the same as that obtained by Ribeiro and Jorge ${ }^{22}$ in the same hospital between 1981 and 1990.

No statistical difference was observed between the distribution of dry bites and the sex of the patient. Similarly, no difference occurred in severity in relation to the sex of the patient. These results are consistent with the literature ${ }^{13,17}$.

No statistical difference was determined between the severity of cases and the age of patients when divided into children, adults and elderly groups. Previous studies reported no association between the bite severity and the age of the patient in relation to Bothrops sensu lato cases ${ }^{22,27}$.

Regarding the sex of the snake, there is scant literature regarding the comparison of venoms from male and female specimens of the same species. One study reported that females of Bothropoides jararaca produce larger amounts of venom $(220 \mathrm{mg})$ with higher protein content and higher lethal activity compared to males $(40 \mathrm{mg})^{28}$. The venom activity of females demonstrates increased hemorrhagic action, while male venom shows greater procoagulant action $^{28}$. However, the present study verified no difference in the occurrence of dry bites in relation to the sex of the snake.

No statistical difference was observed between the occurrence of dry bites and the maturity of the snake. However, when dry bites are excluded from the analysis, observation showed that the median SVL of snakes in mild and moderate cases was $40.5 \mathrm{~cm}$, while in severe cases it was $99 \mathrm{~cm}$. In agreement with these results, other studies with Bothropoides jararaca and Bothrops moojeni showed that accidents caused by juvenile snakes rarely cause severe cases of envenomation ${ }^{29,30}$. Furthermore no statistical difference was verified between the presence of stomach contents and the occurrence of dry bites. This relation was also not observed in Russell's Viper (Daboia russelli siamensis) studies ${ }^{21}$.

Analysis revealed that dry bites occurred at the same frequency over each year studied. However, such cases were more frequent during the spring and summer months.

The use of a tourniquet by patients did not correlate with the presence of a dry bite. The use of a tourniquet can compromise venous return and lymphatic flow of an affected limb and can cause edema formation. In turn, the presence of this type of edema can be misinterpreted by the physician as being caused by the presence and action of Bothrops sensu lato venom. According to França ${ }^{5}$, the use of a tourniquet can contribute to the severity of the bite site, especially in envenoming with local inflammatory activity on the inflicted limb.

Regarding the anatomical area of the cases, the legs were more frequently affected, in $60 \%$ of cases, compared with the arms (39\%). Only $1 \%$ of cases involved the head or trunk. This finding is in agreement with other national studies ${ }^{14-16}$.

Dry bites are relatively more common (7.5:1) in the arms than in the legs $(\mathrm{p}<0.001)$. It appears that cases involving the arms, between juvenile:adult snakes, occur in a 3:1 ratio and in the legs, in a 2:1 ratio. However, when evaluating all cases of dry bite involving the use of a tourniquet, it appears that they are used more frequently (1:2 ratio) on the legs than on the arms (1:3 ratio) and are responsible for edema in such cases.

A significant difference was verified between severity and a time interval greater than 6 hours between the bite and hospital admission. Patients arriving later tend to present more severe reactions $(p=0.009)$. These results are consistent with official data ${ }^{1}$ in which the lethality of Bothrops sensu lato accidents treated in less than six hours was $0.5 \%$, while in those treated after 12 hours lethality was $1.5 \%^{3}$.

A significant association was determined between gingival bleeding and abnormal blood coagulability. A study conducted in the HVB between 1989 and 1991, involving 100 patients bitten by Bothropoides jararaca, observed that patients with systemic bleeding upon hospital admission presented thrombocytopenia ${ }^{31}$. In contrast, patients with local bleeding had identical platelet counts compared to patients without bleeding. The authors concluded that thrombocytopenia at admission is associated with the development of systemic bleeding and the severity of the accident ${ }^{31}$.

Necrosis was more common in the digits of the feet and hands (4.8\%) compared to other body regions (1.8\%). According to Ribeiro $^{26}$, necrosis is associated with the bite site, occurring more frequently in the fingers due to a high concentration of venom in regions with minor circulation. We believe that the likelihood of developing compartment syndrome of the legs is higher than in other regions of the body.

In accidents caused by adult snakes, necrosis was more frequent (7.2\%) compared to accidents caused by juvenile snakes (1\%), since larger snakes can inoculate larger amounts of venom ${ }^{8}$. It may also be related to the difference in dietary habits discussed previously ${ }^{6}$.

The identification of 35 cases where the presence of pre-hospital adjuncts at the site of the bite were verified (including tourniquet, incision and substance use), suggests that the degree of knowledge 
of the population regarding the immediate management of snake bites is suboptimal and can cause increased morbidity. Furthermore, considering the three different time periods in this study, no trend indicating the reduction of these measures was observed, which implies that collective knowledge concerning these potentially harmful pre-hospital practices has not changed. The only variable that showed statistical significance was the time between the bite and hospital admission for these three periods, in which $4.5 \%$ of patients were admitted after 6 hours over the first five-year period, $2.4 \%$ over the second period and $1.5 \%$ over the final period $(\mathrm{p}<0.05)$.

In this work, the associations between some epidemiological data in the clinical picture of Bothropoides jararaca accidents with important snake parameters are highlighted. Further studies are required focusing on different species, in different epidemiological settings and other biogeographic regions. These together with evaluation of the quality of Health Care Services could contribute to improving current understanding regarding this important and neglected disease.

\section{ACKNOWLEDGMENTS}

The authors would like to thank the clinical staff of Vital Brazil Hospital and colleagues of the Laboratory of Herpetology at the Butantan Institute. The authors are also grateful to the patients included in this study and to MD Alexander Kumar for kindly reviewing the English text.

\section{CONFLICT OF INTEREST}

The authors declare that there is no conflict of interest.

\section{REFERENCES}

1. Fenwick AM, Gutberlet-Jr RL, Evans J, Parkinson CL. Morphological and molecular evidence for phylogeny and classification of South American pitvipers, genera Bothrops, Bothriopsis, and Bothrocophias (Serpentes: Viperidae). Zool J Linn Soc 2009; 156:617-648.

2. Ministério da Saúde. Secretaria de Vigilância em Saúde. Sistema de Informação de Agravos de Notificação. SINAN. [Internet]. [Acessado em 07/05/2010]. Disponível em http://dtr2004.saude.gov.br/sinanweb/index.php.

3. Wen FH. Programa Nacional de Vigilância dos Acidentes por Animais Peçonhentos: situação atual. Secretaria de vigilância em saúde. Ministério da saúde. [Internet]. [Acessado em 07/01/09]. Disponível em http://portal.saude. gov.br/portal/saude/default.cfm.

4. Oliveira RC, Wen FH, Sifuentes DN. Epidemiologia dos acidentes por animais peçonhentos. In: Cardoso JL, Haddad-Jr V, França FOS, Wen FH, Malaque CMS editors. Animais peçonhentos do Brasil: biologia, clínica e terapêutica. $2^{\mathrm{a}}$ ed. São Paulo: Sarvier; 2009. p.6-21.

5. França FOS, Barbaro KC, Fan HW, Cardoso JLC, Sano-Martins IS, Tomy SC, et al. Envenoming by Bothrops jararaca in Brazil: association between venom antigenaemi and severity at admission to hospital. Trans R Soc Trop Med Hyg 2003; 97:312-317.

6. Sazima I. Natural history of the jararaca pitviper Bothrops jararaca, in southeastern Brazil. In: Schuett GW, Hoggren M, Douglas ME, Greene HW, editors. Biology of the vipers. Camel-Indiana: Eagle Mountain Publishing; 2002. p. 199-216.

7. Melgarejo AR. Serpentes peçonhentas do Brasil. In: Cardoso JL, Haddad-Jr V, França FOS, Wen FH, Malaque CMS, editors. Animais peçonhentos do Brasil: biologia, clínica e terapêutica. $2^{\text {a }}$ ed. São Paulo: Sarvier: 2009. p. 42-70.

8. França FOS, Málaque CMS. Acidente botrópico. In: Cardoso JL, Haddad Jr V, França FOS, Wen FH, Malaque CMS, editors. Animais peçonhentos do Brasil: biologia, clínica e terapêutica. $2^{\text {a }}$ ed. São Paulo: Sarvier; 2009. p. 81-95.
9. Cardoso LC. Ofidismo. Aracneísmo. Escorpionismo. Epidemiologia. Patogenia e clínica. Diagnóstico e terapêutica. In: Soerensen B, editor. Acidentes por animais peçonhentos. Reconhecimento, clínica e tratamento. Rio de Janeiro: Atheneu; 2000. p. 3-5.

10. Harris JB, Faiz A, Rahman MR, Jalil MA, Ahsan F, Theakston DG, et al. Snake bite in Chittagong Division, Bangladesh: a study of bitten patients who developed no signs of systemic envenoming. Trans R Soc Trop Med Hyg 2010; 104:320-327.

11. Warrell DA. Guidelines for the management of snake-bites. World Health Organization. Library Cataloguing-in-Publication data; 2010. p. 34.

12. Silveira PVP, Nishioka SA. Venomous snake bite without clinical envenoming ('dry-bite'). Trop Med Int Health 1995; 47:82-85.

13. Fundação Nacional da Saúde. Manual de diagnóstico e tratamento de acidentes por animais peçonhentos. 2a ed. Brasília: Ministério da Saúde; 2001.

14. Borges CC, Sadahiro M, Santos MC. Aspectos epidemiológicos e clínicos dos acidentes ofídicos ocorridos nos municípios do Estado do Amazonas. Rev Soc Bras Med Trop 1999; 32:637-646.

15. Feitosa RFG, Melo IMLA, Monteiro HSA. Epidemiologia dos acidentes por serpentes peçonhentas no estado do Ceará - Brasil. Rev Soc Bras Med Trop 1997; 30: 295-301

16. Mise YF, Lira-da-Silva RM, Carvalho FM. Envenenamento por serpentes do gênero Bothrops no estado da Bahia: aspectos epidemiológicos e clínicos. Rev Soc Bras Med Trop 2007; 40:569-573.

17. Nascimento SP. Aspectos epidemiológicos dos acidentes ofídicos ocorridos no Estado de Roraima, Brasil, entre 1992 e 1998. Cad Saude Publica 2000; 16:271-276.

18. Pacheco UP, Zortéa M. Snakebites in southwestern Goiás state, Brazil. J Venom Anim Toxins Incl Trop Dis 2008; 14:141-151.

19. Tinoco HB, Norberg AN, Pile R, Carvalho CRP, Silva DA, Guerra-Sanches F Snake envenomations in northwest counties of the Rio de Janeiro state, Brazil. J Venom Anim Toxins Incl Trop Dis 2005; 11:34-38.

20. Sazima I. Um estudo de biologia comportamental da jararaca, Bothrops jararaca com uso de marcas naturais. Mem Inst Butantan 1988; 50:83-89.

21. Tun-Pe, Ba-Aye, Aye-Aye-Myint, Tin-Nu-Swe, Warrell DA. Bites by Russell's vipers (Daboia russelii siamensis) in Myanmar: effect of the snake's length and recent feeding on venom antigenaemia and severity of envenoming. Trans R Soc Trop Med Hyg 1991; 85:804-808.

22. Ribeiro LA, Jorge MT. Acidentes por serpentes do gênero Bothrops: serie de 3.139 casos. Rev Soc Bras Med Trop 1997; 30: 475-80.

23. Milani R, Jorge MT, Ferraz-de-Campos FP, Martins FP, Bousso A, Cardoso JLC et al. Snake bites by the jararacuçu (Bothrops jararacussu): clinicopathological studies of 29 proven cases in São Paulo state, Brazil. QJM 1997; 90:323-334.

24. Oliveira AL, Pinto JLF, Fonseca ALA, Caputto LZ, Fonseca FLA. Avaliação epidemiológica e laboratorial de pacientes que sofreram acidente ofídico na cidade de Miracatu (Vale do Ribeira, São Paulo). Rev Patol Trop 2008; 37:268-274.

25. Paula-Neto JB, Ribeiro RSP, Luz JA, Galvão M, Carvalho SMD, Haddad-Jr V. Clinical and epidemiological characteristics of injuries caused by venomous snakes observed at the hospital for tropical diseases of Araguaína, Tocantins state, Brazil, from 1995 to 2000. J Venom Anim Toxins Incl Trop Dis 2005; 11:422-432.

26. Ribeiro LA, Jorge MT, Lebrão ML. Prognostic factors for local necrosis in Bothrops jararaca (Brazilian pit viper) bites. Trans R Soc Trop Med Hyg $2001 ; 95: 630-634$

27. Ribeiro LA, Gadia R, Jorge MT. Comparação entre a epidemiologia do acidente e a clínica do envenenamento por serpentes do gênero Bothrops, em adultos idosos e não idosos. Rev Soc Bras Med Trop 2008; 41:46-49.

28. Furtado MFD, Travaglia-Cardoso SR, Rocha MMT. Sexual dimorphism in venom of Bothrops jararaca (Serpentes: Viperidae). Toxicon 2006; 48:401-410.

29. Kouyoumdjian JA, Polizelli C. Acidentes ofídicos causados por Bothrops moojeni: correlação do quadro clínico com o tamanho da serpente. Rev Inst Med Trop São Paulo 1989; 31:84-90.

30. Ribeiro LA, Jorge MT. Epidemiologia e quadro clínico dos acidentes por serpentes Bothrops jararaca adultas e filhotes. Rev Inst Trop São Paulo $1990 ; 32: 436-442$

31. Santoro ML, Sano-Martins IS, Wen HF, Cardoso JLC, Theakston RDG, Warrell DA, et al. Haematological evaluation of patients bitten by the jararaca, Bothrops jararaca, in Brazil. Toxicon 2008; 51:1440-1448. 